\title{
PRE-MARRIED EDUCATION URGENTION AS AN EFFORT TO PREPARE WIFE HUSBANDS FOR MARRIAGE
}

\author{
Abdul Hadi Ismail \\ Faculty of Islamic Studies, Universitas Muhammadiyah Sumatera Utara \\ abdulhadi@umsu.ac.id
}

\begin{abstract}
The birth of BP4 was motivated by the high divorce rate, rampant child marriage and unhealthy polygamy. Over time, one of BP4's duties is to organize pre-marriage courses, as an effort to create a sakinah household, mawaddah warahmah. The method is normative juridical, This research is a descriptive analysis with a conceptual approach. The data source of this research is a secondary data source, the data collection tool is a research library. To analyze the data used qualitative data analysis. BP4 in its duties conducts pre-marital courses, provides material related to understanding marriage and domestic life, maintains good communication between prospective married couples, provides procedures for resolving conflicts in the household. Based on these conditions, BP4 has a heavy duty, function and role. This means that the good and bad of a marriage also depends on the functioning and role of the BP4. .
\end{abstract}

Keywords: Education, Pre-marriage, Marriage..

\section{Journal History}

Received : August 24, 2020;

Reviewed : October 7, 2020;

Accepted : October 28, 2020;

Published : November 1, 2020

Copyright@2020 NLR. All right reserved. 


\section{INTRODUCTION}

Marriage according to Islamic law which is in accordance with the philosophical foundation of marriage based on Pancasila, is regulated in Article 1 of Law Number 1 of 1974 concerning Marriage, by linking marriage based on the first principle, namely God Almighty. This philosophical foundation is then emphasized through Article 2 of the Compilation of Islamic Law (KHI), which contains: 1. Marriage solely obeying Allah's orders, 2. Carrying out marriage is worship, 3. Marriage ties are mitsaaqangholiidhan (strong ties).

In that philosophical foundation, then it is summarized between faith, worship and muamalah. Marriage is a sacred ritual where two people who love each other meet, without any boundaries that hinder one another. ${ }^{1}$ In fact, many parties take advantage of these rituals only to gain profit, either in the form of material or simply to get sexual satisfaction or for other reasons. Responding to the religious and state law provisions related to marriage, giving an important signal to both the people and citizens that legal marriage is compulsory for

${ }^{1}$ Soelaeman, Pendidikan dalam Keluarga, (Bandung: Alfabeta, 1994), p. 12.

2 Hakim, Nurul, "Mengkaji Kembali Eksistensi Mahar Perkawinan Di Aceh Pidie Sebagai Upaya Meminimalisasi Rendahnya Angka Perkawinan Pada Pasangan Usia Mapan (Rencangan Konsep Mahar: Sebuah Revitalisasi Syari'at Islam Dan Hukum those who have met the requirements. $^{2}$

Even though it has fulfilled the marriage requirements stipulated by religious law (Islam) and State law, in fact there is still a lot of increasing divorce rate in Indonesia. Every year the divorce rate continues to increase for various reasons. Throughout 2018, the Class IA Medan Religious Court handled thousands of divorce cases. Starting from divorce talak (divorce filed by the husband / man), divorce lawsuit (divorce filed by the wife / woman). The biggest problem in the Religious Courts (PA) is divorce, where the number of cases during 2018 was 2,620.

Based on the Balitbang data from the Ministry of Religion, that of the divorce rate, more than $70 \%$ are claimants or women are suing for divorce. This is reinforced by data in seven regions, namely in Aceh, Padang, Cilegon, Indramayu, Pekalongan, Banyuwangi and Ambon. ${ }^{3}$

Based on the results of research conducted by Husin Anang Kabalmay, that in Ambon the causes of divorce were: 1) unhealthy polygamy; (2) moral crisis; (3) forced marriage; (4) economy; (5) no

Adat)", Juridikti: Jurnal Ilmiah Pendidikan Tinggi, Vol. 3, No. 3, Desember (2014), p. 49.

Muhammad, Syafaat, "Fenomena Cerai Gugat di Kabupaten Kuningan: Sebuah Kajian Perubahan Sosial dalam Masyarakat dan Sosial", Jurnal Bimas Islam, Volume 9, Nomor 4, Tahun (2016), p. 604. 
responsibility; (6) persecution; (7) there is no harmony. ${ }^{4}$

Research conducted by Harjianto and Roudhatul Jannah resulted in data that the causes of divorce in Banyuwangi Regency were economic factors, responsibility, third parties, and harmony. The results showed that the reason for divorce was due to economic factors (37.5 percent). The economic problem that arises is that the husband is deemed unable to meet the needs of his household, because his income is mediocre so that he cannot fulfill the family's needs. The sustainability and happiness factors of a marriage are very much influenced by their financial life. The necessities of life will be fulfilled properly if the husband and wife have adequate financial resources. Income or income is a very important thing in the family. With sufficient income, it can provide physical and mental satisfaction as the fulfillment of all family needs. ${ }^{5}$

Based on some of the studies mentioned above, there is one common thread from the results of the research related to the factors of divorce, namely the unpreparedness of a married couple to undergo a household ark which is actually full of obstacles and challenges that are not small. It takes a strong mentality,

4 Kabalmay, Husin Anang, "Kebutuhan Ekonomi Dan Kaitannya Dengan Perceraian (Studi Atas Cerai Gugat Di Pengadilan Agama Ambon)", Tahkim, Vol. XI, No. 1, Juni (2015), p. 52. more patience and very high fortitude, because marriage unites two families with different cultures, ethnicities, education and social levels.

Actually, the government has formed a Marriage Advisory and Preservation Agency (BP4) which is one of the elements in the Office of Religious Affairs (KUA) which has an important role and carries the vision of realizing a sakinah family. The existence of this institution is expected to be able to play an active role in the success of the national program, namely the sacinan family movement and also as the goal of Islam.

The Marriage Advisory and Preservation Agency (BP4) was formed to provide education so that an understanding of the values of marriage can be understood by prospective married couples. In fact, many BP4s do not carry out their proper functions, so that the premarital education that should have been implemented was not carried out at all.

Based on the above arguments, it is appropriate to study and examine further related to the regulation of the duties and functions of BP4 and how to implement the role and function of BP4 in pre-marital education.

\section{METHOD}

5 Harjianto, Roudhotul Jannah, "Identifikasi Faktor Penyebab Perceraian Sebagai Dasar Konsep Pendidikan Pranikah di Kabupaten Banyuwangi,", Jurnal Ilmiah Universitas Batanghari Jambi, Vol. 19, No. 1, Februari (2019), p. 37. 
This research is a descriptive analysis with a conceptual approach. The data source of this research is a secondary data source, the data collection tool is a research library. To analyze the data used qualitative data analysis.

\section{DISCUSSION}

There are two words which denote marriage, namely kawin in Indonesian and nikah in Arabic. Marriage comes from Arabic, namely: نكح-

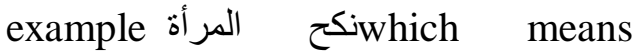
marrying a woman. ${ }^{6}$ Anwar Harjono said that the word marriage is the same as the word zawaj in the term fiqh. $^{7}$ The term zawaj is then translated into Indonesian as marriage. ${ }^{8}$

The term mating, when used in general, can be used for humans, animals and plants as the only way to reproduce naturally. In humans, marriage is used because it contains legal validity, both customary, national law, and according to religion. The meaning of marriage is a contract or bond, because in a marriage process there is a consent (a statement of submission from the woman's side, usually the guardian), and kabul (a statement of acceptance from the male party). Marriage, in the classical fiqh perspective, is defined as intercourse or intercourse. ${ }^{9}$

\footnotetext{
${ }^{6}$ Ma'luf, Louis, al-Munjid fi alLughah wa al-Adab wa al- 'Ulum, (Beirut: Dar al-Masyriq, 1986), p. 836.

${ }^{7}$ Harjono, Anwar, Hukum Islam Keluasan dan Keadilannya, (Jakarta: Bulan Bintang, 1987), p. 220.
}

The word "nikah" is also often used to express the meaning of marriage. The Koran itself uses the word "marriage" rather than zawaj in its narrative regarding marriage. Surat al-Baqarah verse 235:

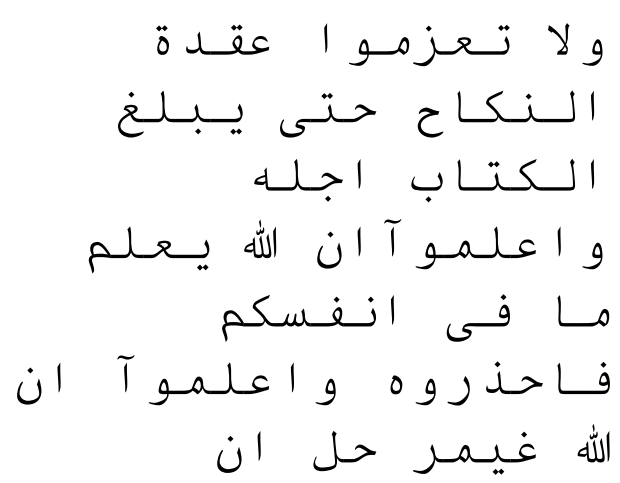

"(And do not commit yourself to a marriage ceremony, before the iddah period is over. And know that Allah knows what is in your heart, so fear Him and know that Allah is Forgiving, Most Forgiving)".

Mathlub said that etymologically, marriage is used to express the meaning of copulation, contract, and hug. For example, its use in sexual intercourse is exemplified in the words of the Prophet Muhammad, "I was born from the result of marriage, not the result of prostitution", that is sexual

8 Hasan, Mustofa, Pengantar Hukum Keluarga, (Bandung: Pustaka Setia, 2011), p. 47.

${ }^{9}$ Tihami, Sohari Sahrani, Fikih Munakahat (Kajian Fiqih Nikah Lengkap), (Jakarta: PT RajaGrafindo Persada, 2014), p. 7. 
intercourse which is halal, not haram. ${ }^{10}$

Marriage is one of the main principles in human life which is the main part of the association in a perfect form of society. Marriage is one of the most noble ways to organize a human life system that is more orderly and civilized to carry on offspring. Marriage is also seen as a way to get to know one another from one group to another so that mutual help occurs. ${ }^{11}$

Marriage is a part of noble morals from an Islamic perspective. Morals are very basic things in Islamic teachings, both morals towards Allah, fellow humans and towards the natural surroundings. ${ }^{12}$ The provisions of marriage which have been regulated in the Qur'an are authentic evidence that it is not only a religious book and of course contains moral and ethical elements. ${ }^{13}$

Tutik said that marriage is a life partnership between a man and a woman which is formally confirmed through the law, namely juridically and mostly religiously according to the purpose of husband and wife and the law, carried out for the rest of his

10 Mathlub, Abdul Majid Mahmud, Panduan Hukum Keluarga Sakinah, (Solo: Intermedia, 2005), p. 2.

${ }^{11}$ Santoso, "Hakekat Perkawinan Menurut Undang-Undang Perkawinan, Hukum Islam Dan Hukum Adat", Yudisia: Jurnal Pemikiran dan Penelitian Sosial Keagamaan, Vol. 7, No. 2, Desember (2016), p. 417.

12 Yatimin, Thamrin, "Strategi Pembelajaran Akidah Akhlak Untuk Madrasah Tsanawiyah Propinsi Riau", life according to the institution of marriage. ${ }^{14}$ In the Civil Code, the definition of marriage is not strictly regulated. Article 26 views marriage only in terms of a civil relationship. Article 27 states that marriage adheres to the principle of monogamy. Article 103 states that husband and wife must be faithful to each other, please help and help help. Nurhayani in Nurhadi said that marriage is a bond between a man and a woman which is legally recognized by state legislation and aims to form an eternal family. ${ }^{15}$

According to Article 1 paragraph (2) of Law Number 1 of 1974 concerning Marriage, marriage is defined as:

"The inner and outer bond between a man and a woman as husband and wife with the aim of forming a family, a happy and eternal household based on the Supreme Lordship".

Based on the definition of marriage in Law Number 1 of 1974 concerning Marriage, it explains that marriage in Indonesia has a close correlation with religion / spirituality, so that marriage not only has a physical / physical element, but an

Al-Fikra: Jurnal Ilmiah Keislaman, Vol. 16, No. 1, Januari-Juni (2017). p. 155.

${ }^{13}$ Nurhadi, "Maqashid Syari'ah Hukum Perkawinan Dalam Kompilasi Hukum Islam (KHI)", Al-Fikra: Jurnal Ilmiah Keislaman, Vol.16, No. 2, JuliDesember (2017), p. 205.

${ }^{14}$ Tutik, Titik Triwulan, Hukum Perdata dalam Hukum Nasional, (Jakarta: Kencana Prenada Media Group, 2008), p. 106.

${ }^{15}$ Ibid., p. 208. 
inner / spiritual element also plays a very important role. ${ }^{16}$

According to Article 2 of the Compilation of Islamic Law, that marriage is a very strong contract or mitsaqanghalidhan to obey Allah's orders and carry out them is worship. The purpose of marriage according to Islamic law consists of:

1. Being devoted to Allah;

2. Marriage is the most important thing in human life, which is fulfilling our human nature because men and women need each other;

3. As a way of human regeneration / descent;

4. Marriage can calm the spiritual life between man and woman;

5. As a means to get closer to each other so as to create a sense of mutual understanding between humans in an effort to maintain life safety. ${ }^{17}$

The five purposes of marriage are based on the narrative contained in the Al-Qur'an SuraAr-Ruum verse $21 .{ }^{18}$ Marriage is a form of protection for women from treatment that undermines their dignity and selfrespect. Marriage is mandatory, because marriage is an institution that gives a man the legality of protecting the woman who becomes his wife.

${ }^{16}$ Hadikusuma, Hilman, Hukum Perkawinan Indonesia (Menurut Perundangan, Hukum Adat, Hukum Agama), (Bandung: Mandar Maju, 2007), p. 21.

${ }^{17}$ Santoso, "Hakekat Perkawinan Menurut Undang-Undang Perkawinan, Hukum Islam Dan Hukum Adat", dalam Yudisia: Jurnal Pemikiran dan Penelitian
The purpose of marriage in Islam is to foster human morals, humanize humans (because sexual relations without being preceded by a marriage contract are the same as marriage that occurs between animals), to build relationships between two different sexes so that they are able to build a new life socially and culturally. Various relationships that are united in one household to form a generation that will benefit the future of society and the State of course. ${ }^{19}$

Ahmad Rofiq said that there are 6 basic principles of marriage contained in Law Number 1 of 1974 concerning Marriage, namely:

1. Marriage aims to form a happy and eternal family, and to achieve this, husband and wife need to help and complement each other so that they can develop their respective personalities in order to achieve prosperity both spiritually and materially.

2. A marriage is valid if it is carried out according to each religion and belief, and the marriage must be recorded.

3. Marriage in the Marriage Law adheres to the principle of monogamy.

Sosial Keagamaan, Vol. 7, No. 2, Desember (2016), p. 417.

${ }^{18}$ Djamali, Abdul, Hukum Islam (Berdasarkan Ketentuan Kurikulum Konsorsium Ilmu Hukum, (Bandung: Mandar Maju, 2002), p. 79-80.

19 Saebani, Beni Ahmad, Fiqh Munakahat 1, (Bandung: Pustaka Setia, 2009), p. 19-20. 
4. The prospective husband and wife must have their body and soul mature in order to carry out a marriage, the goal of which is to achieve the goal of marriage and there is no thought of divorcing, and to have good offspring.

5. In principle, this Marriage Law makes divorce difficult, because the purpose of marriage is to form a happy and eternal family.

6. Husbands and wives have equal rights and positions, both in the household and in social life in the community. ${ }^{20}$

Based on the explanation above, marriage in Islam is prescribed not only to satisfy the sexual lust that exists in humans, but more than that, namely to regulate the social system of society so that it can live humanely, socially orderly, build inter-ethnic relations. and race, so that they can work together in a household, to form a good generation because it begins with a good marriage. Marriage is a series of natural processes of human life, containing essential elements that are psychological and spiritual in nature.

The Urgency of Prenuptial Education in Realizing a Sakinah, Mawaddah and Rahmah Marriage

Indeed, marriage requires physical, psychological and emotional maturity, so that it is able

20 Rofiq, Muhammad, "Pendidikan Pranikah Untuk Membentuk Keluarga Sakinah, Mawaddah, Wa Rahmah (Studi di Komunitas Rumah to face various obstacles and challenges that cannot be said to be light. A married couple with a background in customs, upbringing and education, different environments, has the potential for divorce if they are not given good and measured knowledge. The presence of pre-marriage education, premarriage guidance, pre-marriage courses or other equivalent terms, actually aims to provide an understanding of marriage and its details, thereby minimizing the potential for divorce between married couples.

Pre-marriage education is a process or effort to provide a transformation of knowledge that teaches better and more comprehensive values and skills related to marriage, before the marriage takes place for the two prospective brides.

In terms of pre-marriage courses according to the Regulation of the Director General of Islamic Community Guidance Number DJ.II / 542 of 2013 concerning Guidelines for the Implementation of PreMarriage Courses, pre-marriage courses are: "providing knowledge, understanding, skills, and raising awareness to adolescents of marriage age about life. household and family. Before the term pre-marriage course was used, the term used was family guidance. Family guidance is regulated in the Regulation of the

Jodoh (KRJ) Salatiga)". Skripsi. Fakultas Tarbiyah dan Ilmu Pendidikan, Institut Agama Islam Negeri Salatiga, 2018, p. 56-57. 
Director General of Islamic Community Guidance No. DJ.11 / 491 of 2009 regarding the Candidate Bride Course. In 2013 the name of the pre-marriage guidance program was changed to the title pre-marriage course. $^{21}$

Senediak said that pre-marital education is training that enables married couples to have important knowledge and skills to maintain and improve husband and wife relationships when married. ${ }^{22}$ Premarriage guidance is carried out as one of the efforts to help the prospective bride and groom carried out by professional counselors, which aim that the prospective bride and groom can develop and be able to solve the problems they will face in the household through ways of mutual respect, full of tolerance accompanied by good communication. it has mutual understanding, which in the end will be achieved by a family that is full of motivation, full of positive development, has independence and the realization of welfare for all family members. ${ }^{23}$

\footnotetext{
21 Iskandar, Zakkyah, "Peran Kursus Pra Nikah Dalam Mempersiapkan Pasangan Suami-Istri Menuju Keluarga Sakinah", dalam Jurnal Al-Ahwal, Vol. 10, No. 1, Juni (2017), p. 89.

22 Kurniawan, Irwan Nuryana, "Pendidikan Pranikah dan Pengasuhan Islam bagi Calon Pasangan Suami Istri: Respon Psikologi Keluarga terhadap Siklus Tahunan Perceraian dan Kekerasan terhadap Anak di Indonesia", melalui

http://www.researchgate.net.kurniawan2 o16-pendidikan-pernikahan-dan-
}

Guidance, including premarriage, pre-marital education, premarriage courses, especially for Muslims, is concentrated on providing knowledge for prospective brides who want to get married as a provision to increase knowledge while fostering domestic life. This pre-marriage course, pre-marriage education, or pre-marriage guidance is very urgent considering that marriage is not only meant by the union of a man and woman in a household bond, but marriage is a sacred worship that has enormous rewards and has the power to change the perpetrator at once. his nervous power was also very high. The premarriage course provided by professionals is not only seen from the perspective of the Islamic religion but is also accompanied by various sciences which are self-empowerment in accordance with the times. The materials include marriage, financial management, educating children and many other materials. ${ }^{24}$

When viewed from legal considerations, the concerns of the

pengasuhan.pdf., accessed on 29 (Juli 2020).

${ }^{23}$ Roiatun, Siti, "Bimbingan Pra Nikah Untuk Mencegah Perceraian Bagi Calon Pengantin Di BP4 KUA Kecamatan Japah Kabupaten Blora". Skripsi. Fakultas Dakwah dan Komunikasi, Universitas Islam Negeri Walisongo, Semarang, 2017, 17-18.

$\begin{array}{llr}{ }^{24} & \text { Nofiyanti, "Layanan } \\ \text { Bimbingan Pra Nikah dalam } \\ \text { Meningkatkan } & \text { Kematangan Emosional } \\ \text { Berkeluarga", Jurnal Prophetic, Vol. I, } \\ \text { No. I, November (2018), p. } 120 .\end{array}$


counter parties to this decision are actually groundless. Precisely this ruling gives a moral message to men not to carelessly have sex outside of marriage, because there are implications that will be accounted for as a result of his actions. The Court intends that children born outside marriage get adequate legal protection, because in principle the child is not sinful because his birth is out of his will. Children born without a clear father status often get unfair treatment and stigma in the midst of society. The law must provide fair legal protection and certainty for the status of a child who is born and the rights that he has, including for children born even though the validity of his marriage is still disputed (see MK Decision No. 46 / PUU-VIII / 2010). ${ }^{25}$

The urgency of pre-marriage courses, pre-marital guidance or premarriage education is a preventive function that prevents something from happening, especially in a household. ${ }^{26}$ This is based on the fact that many studies show the high divorce rate is due to many factors, both economic, psychological, incompatible, infidelity, poor communication between husband and

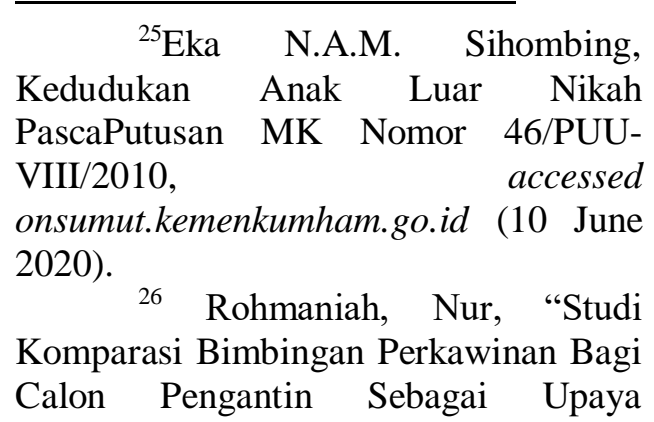

wife, unrealistic expectations of marriage, poor decision-making methods, which make married couples prone to conflicts in marriage. ${ }^{27}$ Based on these facts, premarital education, pre-marriage guidance or pre-marriage courses are important components to be implemented as an effort to save a marriage from the dark side of divorce.

Various empirical scientific evidence has provided many concrete answers that the existence of a skillsbased pre-marital education program can actually increase satisfaction and improve commitment to maintaining healthy relationships between husband and wife. Various studies evaluating pre-marital education show the fact that participants consisting of various ethnicities / cultures, different levels of family income and various forms of family structure actually benefit from being involved in the pre-marital education program. These benefits include increased knowledge about the ins and outs of a husband and wife relationship, including the ability to read and recognize patterns of unhealthy relationships in marriage. ${ }^{28}$

Brammer and Shostrom view that pre-marriage guidance aims to help prospective married couples

Mencegah Perceraian (Di KUA Kecamatan Boja dan Limbangan Kabupaten Kendal)". Skripsi. Fakultas Dakwa dan Komunikasi Universitas Islam Negeri Walisongo Semarang, 2015 , p. 31.
${ }^{27}$ Kurniawan, Op. Cit.
${ }^{28}$ Ibid. 
understand well about themselves, each partner, and the demands of marriage, so that the decision to marry is more stable and able to adapt to each other. each when already married. ${ }^{29}$

Pre-marriage education teaches the prospective bride to understand the personality of each candidate, the appropriate patterns of adjustment for each prospective bride. The need to understand the personalities of oneself and the prospective bride and groom is very important because many divorces occur as a result of small habits that are not liked by husband or wife. ${ }^{30}$ Premarital guidance is a therapy for couples who are about to get married. The therapy is used to help the bride and groom to understand each other, so that all problems and conflicts that occur in the household can be resolved in a healthy manner, respect for differences, and improve good communication patterns. ${ }^{31}$

Pre-marriage guidance, premarital education, and pre-marriage courses all aim to help the prospective bride and groom prevent various problems related to marriage, by:

1. Helping the prospective bride and groom to understand the nature of marriage in Islam,

2. Helping the bride and groom to know the purpose of marriage in Islam,

\footnotetext{
${ }^{29}$ Roiatun, Op. Cit., hlm. 18.

${ }^{30}$ Ibid., hlm. 47.

31 Kertamuda, Fatchiah E, Konseling Pernikahan untuk Keluarga
}

3. Helping the bride and groom understand the various requirements of marriage according to Islam,

4. Helping the prospective bride understand her readiness to run the marriage,

5. Helping each prospective bride to carry out a marriage in accordance with the provisions of Islamic law. ${ }^{32}$

\section{Role and Functions of the Marriage Preservation Advisory Agency (BP4) in the implementation of the Pre-Marriage Course}

Based on the Decree of the 2014 XV National Marriage Advisory, Development and Preservation Agency (BP4) Number 260/2-P / BP4 / VIII / 2014 concerning the Articles of Association of the 2014 Marriage Advisory, Guidance and Preservation Agency (BP4), BP4 is a professional organization. which is socio-religious as a partner of the Ministry of Religion of the Republic of Indonesia and related agencies in the task of improving the quality of marriage by developing the sakinah family movement.

In the Islamic Encyclopedia, BP4 (Marriage Guidance and Preservation Agency) is a semiofficial organization under the Ministry of Religion that works in providing marriage advice, disputes

Indonesia, Jakarta: Salemba Humanika, 2009, hlm. 136.

32 Fakih, Aunur Rahim, Bimbingan dan Konseling Dalam Islam, (Yogyakarta: Jendela, 2001), p. 84. 
and divorce. ${ }^{33}$ BP4 has received juridical recognition from the government, namely through the Minister of Religion Decree No. 85 of 1961, which has established BP4 as the only body engaged in the field of marriage advice and divorce prevention. $^{34}$

$\mathrm{BP} 4$ is a profession that carries out the duties and partners of the Ministry of Religion in an effort to create

a sakinah family ,mawaddahwarahm ah. BP4, formerly known as the Marriage Dispute and Divorce Advisory Board (BP4), is an official government agency whose task is to assist the Ministry of Religion in matters of family development. The birth of BP4 was motivated by the high rate of divorce that occurred in 1950 to $1954 .{ }^{35} \mathrm{BP} 4$ was born to handle divorce issues so that married couples get guidance. ${ }^{36}$ Another thing behind the birth of BP4 is the number of underage marriages and the many unhealthy practices of polygamy.

One of the tasks of BP4 is to organize pre-marriage courses for prospective brides who want to get married. Actually, the pre-marriage course is not only aimed at potential couples who want to get married, but for all people who have entered the age of marriage, such as children who are in vocational schools and the

${ }^{33}$ Nasution, Harun, Ensiklopedi Islam, Jilid 1, (Jakarta: Depag RI, 1993), p. 212.

34 Muchtar, Zubaidah, Fungsi dan Tugas BP4: Nasehat Perkawinan dan Keluarga, (Jakarta: Maret, 1993), p. 36. same. These SMK age children need to be given an understanding of family and household, the procedures for living a household life, so that they will create a sakinah family ,mawaddahwarahm ah.

The objectives of BP4 are as stated in the BP4 Articles of Association (AD) and Bylaws (ART), namely:

"Enhancing the quality of marriage in order to create a sakinah family, according to Islamic teachings to achieve an advanced, independent, happy, prosperous, material and spiritual society and nation of Indonesia".

In order to achieve these goals, BP4 has the following businesses: "1) Provide advice and information regarding marriage, divorce, divorce and referrals to those who will do it either individually or in groups. 2) Preventing arbitrary divorce (talak / divorce), irresponsible polygamy, underage marriages and illegal marriages. 3) Providing assistance in overcoming problems of marriage, family and household disputes. 4) Provide guidance and counseling on the Marriage Law and the law of hypocrisy . 5) Cooperating with agencies, institutions and organizations that have the same

35 Latif, Nasaruddin, Biografi dan Pemikiran, (Jakarta: GIP, 1996), p. 7.

36 Rizkiya, Miffa., Santi Marhamah, "Upaya Badan Penasehatan, Pembinaan Dan Pelestarian Perkawinan (BP4) Dalam Pembinaan Dan Pelestarian Perkawinan", Al-Mursalah, Vol. 3, No. 2, Juli-Desember (2017), p. 81. 
goals, both at home and abroad. 6) Publish magazines, books, brochures and so on. 7) Organizing courses, upgrades, discussions, seminars and so on. 8) Increase the appreciation and practice of Islamic teachings in order to foster a healthy, happy and prosperous family (household). 9) Improve the implementation of guidelines for the appreciation and practice of Pancasila in the family. 10) Take an active role in cross-sectoral activities, which aim to build a healthy, happy and prosperous family (household). 11) Other businesses that are considered beneficial for the happiness and welfare of the family. ${ }^{37}$

One of the efforts made by BP4 is pre-marriage courses. Premarriage courses are guidance or education for the prospective bride and groom as a way to provide knowledge for living the household life provided by BP4 officers in providing guidance material for prospective brides as provisions for marital life, family health and others. By providing guidance material or pre-marriage courses, it is hoped that it can improve the quality of the family or achieve a safe household life, mawaddahwarahmah. ${ }^{38}$

${ }^{37}$ Akbar, Ali, Anggaran Dasar dan Anggaran Rumah Tangga BP4, Hasil Munas BP4 VIII, (Semarang: Kantor BP4 Propinsi Jawa Tengah, 1997), p. 10.

38 Fatkhuddin, Muhammad, "Pendidikan Pra Nikah Sebagai Upaya Meminimalisir Perceraian (Studi Model Kursus Pra Nikah di Kementerian Agama Kabupaten Tegal)", La Tahzan: Jurnal
The issuance of Law Number 1 of 1974 concerning Marriage, turned out to change the functions and duties of BP4. Important changes within the body of BP4 are related to the role of BP4 at the district and subdistrict levels. The district BP4 is ex officio headed by the Head of Islamic Affairs (currently the Head of the Islamic Affairs Section), which functions as a mediator for couples who are about to divorce. The subdistrict level BP4 which is ex officio headed by the Head of the KUA, is responsible for fostering married couples. The task of BP4 at the KUA is limited to conducting premarriage advice or courses for prospective brides. This means that the KUA and BP4 are tasked with providing provision for the prospective bride and groom with material that is still limited to figh and marriage ethics in Islam. ${ }^{39}$

Pre-marriage courses are organized by BP4 or other institutions that have received accreditation from the Ministry of Religion (PerdirjenBimas Islam No. DJ.II / 542/2013 Article 3). The regulation also regulates certification, which explains that prospective brides who have passed the pre-marriage course are given a certificate of graduation

Pendidikan Islam, Vol. XI, No. 1, Mei (2019), p. 75.

39 Hidyataulloh, Haris, Laily Hasan, "Eksistensi Badan Penasehatan Pembinaan dan Pelestarian Perkawinan (BP4) Dalam mewujudkan Keluarga sakinah di KUA Peterongan Jombang", Jurnal Hukum Keluarga Islam, Vol. 1, No. 1, April (2016), p. 94. 
and can be used as a condition for registering a marriage. ${ }^{40}$

Pre-marriage courses, premarital guidance, pre-marital education are one of the entry points in the world of marriage, with the existence of pre-marriage courses, it is hoped that it can provide broad insights and deeper knowledge about the ins and outs of household problems so that households can reach prosperous, eternal and eternal in accordance with the mandate of the Marriage Law. In living a household life, the potential for conflict is enormous. Therefore it requires knowledge of methods or procedures for dealing with household dips, through pre-marriage courses, premarriage guidance, or pre-marital education.

\section{CONCLUSION}

Living a household life is not enough just relying on love alone. The marriage that was carried out turned out to have a very large potential for conflict. With different cultural backgrounds, education levels, environmental factors, the potential for conflict is even greater. Based on these facts and conditions, it is necessary to have an institution or body that functions to provide courses, guidance or premarriage education for prospective brides before the marriage takes place. In Indonesian law, BP4 is believed to be an institution that organizes pre-marital courses for prospective brides and people who are about to grow up related to providing knowledge about married life, as well as procedures for overcoming problems that occur in the household.

\section{REFERENCES}

Akbar, Ali, Anggaran Dasar dan Anggaran Rumah Tangga BP4, Hasil Munas BP4 VIII, Semarang: Kantor BP4 Propinsi Jawa Tengah, 1997.

Djamali, Abdul, Hukum Islam (Berdasarkan Ketentuan Kurikulum Konsorsium Ilmu Hukum, Bandung: Mandar Maju, 2002.

Fakih, Aunur Rahim, Bimbingan dan Konseling Dalam Islam, Yogyakarta: Jendela, 2001.

Fatkhuddin, Muhammad, "Pendidikan Pra Nikah Sebagai Upaya Meminimalisir Perceraian (Studi Model Kursus Pra Nikah di Kementerian Agama Kabupaten Tegal)", La Tahzan: Jurnal Pendidikan Islam, Vol. XI, No. 1, Mei (2019).

Hadikusuma, Hilman, Hukum Perkawinan Indonesia (Menurut Perundangan, Hukum Adat, Hukum Agama), (Bandung: Mandar Maju, 2007).

Hakim, Nurul, "Mengkaji Kembali Eksistensi Mahar Perkawinan Di Aceh Pidie Sebagai Upaya Meminimalisasi Rendahnya Cit., hlm. 79.

${ }^{40}$ Fatkhuddin, Muhammad, $O p$. 
Angka Perkawinan Pada

Pasangan Usia Mapan

(Rencangan Konsep Mahar:

Sebuah Revitalisasi Syari'at

Islam Dan Hukum Adat)", dalam Juridikti: Jurnal Ilmiah

Pendidikan Tinggi, Vol. 3,

No. 3, Desember (2014).

Harjianto, Roudhotul Jannah,

"Identifikasi Faktor Penyebab

Perceraian Sebagai Dasar

Konsep Pendidikan Pranikah

di Kabupaten Banyuwangi”,

dalam Jurnal Ilmiah

Universitas Batanghari

Jambi, Vol. 19, No. 1,

Februari (2019).

Harjono, Anwar, Hukum Islam

Keluasan dan Keadilannya, Jakarta: Bulan Bintang, 1987.

Hasan, Mustofa, Pengantar Hukum

Keluarga, (Bandung: Pustaka Setia, 2011).

Hidyataulloh, Haris, Laily Hasan,

"Eksistensi

Badan

Penasehatan Pembinaan dan

Pelestarian Perkawinan (BP4)

Dalam mewujudkan Keluarga sakinah di KUA Peterongan Jombang", dalam Jurnal Hukum Keluarga Islam, Vol. 1, No. 1, April (2016).

Iskandar, Zakkyah, "Peran Kursus

Pra Nikah Dalam

Mempersiapkan Pasangan

Suami-Istri Menuju Keluarga Sakinah", dalam Jurnal AlAhwal, Vol. 10, No. 1, Juni (2017).

Kabalmay, Husin Anang,

"Kebutuhan Ekonomi Dan
Kaitannya Dengan Perceraian (Studi Atas Cerai Gugat Di Pengadilan Agama Ambon)", dalam Tahkim, Vol. XI, No. 1, Juni (2015).

Kertamuda, Fatchiah E, Konseling Pernikahan untuk Keluarga Indonesia, Jakarta: Salemba Humanika, 2009.

Kurniawan, Irwan Nuryana, "Pendidikan Pranikah dan Pengasuhan Islam bagi Calon Pasangan Suami Istri: Respon Psikologi Keluarga terhadap Siklus Tahunan Perceraian dan Kekerasan terhadap Anak di Indonesia", melalui http://www.researchgate.net.k urniawan2016-pendidikanpernikahan-danpengasuhan.pdf., diakses tanggal 29 (Juli 2020).

Latif, Nasaruddin, Biografi dan Pemikiran, (Jakarta: GIP, 1996).

Ma'luf, Louis, al-Munjid fi al-Lughah wa al-Adab wa al-'Ulum, Beirut: Dar al-Masyriq, 1986.

Mathlub, Abdul Majid Mahmud, Panduan Hukum Keluarga Sakinah, Solo: Intermedia, 2005.

Muchtar, Zubaidah, Fungsi dan Tugas BP4: Nasehat Perkawinan dan Keluarga, Jakarta: Maret, 1993.

Muhammad, Syafaat, "Fenomena Cerai Gugat di Kabupaten Kuningan: Sebuah Kajian Perubahan Sosial dalam Masyarakat dan Sosial", 
dalam Jurnal Bimas Islam, Volume 9, Nomor 4, Tahun (2016).

Nasution, Harun, Ensiklopedi Islam, Jilid 1, Jakarta: Depag RI, 1993.

Nofiyanti, "Layanan Bimbingan Pra

Nikah dalam Meningkatkan

Kematangan Emosional

Berkeluarga", dalam Jurnal

Prophetic, Vol. I, No. I,

November (2018).

Nurhadi, "Maqashid Syari'ah Hukum

Perkawinan Dalam Kompilasi

Hukum Islam (KHI)", Al-

Fikra: Jurnal Ilmiah

Keislaman, Vol.16, No. 2, Juli-Desember (2017).

Rizkiya, Miffa., Santi Marhamah,

"Upaya Badan Penasehatan,

Pembinaan Dan Pelestarian

Perkawinan (BP4) Dalam

Pembinaan Dan Pelestarian

Perkawinan", Al-Mursalah,

Vol. 3, No. 2, Juli-Desember (2017).

Rofiq, Ahmad, Hukum Islam di Indonesia, Jakarta: PT RajaGrafindo Persada, 2000.

Rofiq, Muhammad, "Pendidikan Pranikah Untuk Membentuk Keluarga Sakinah, Mawaddah, Wa Rahmah (Studi di Komunitas Rumah Jodoh (KRJ) Salatiga)". Skripsi. Fakultas Tarbiyah dan Ilmu Pendidikan, Institut Agama Islam Negeri Salatiga, 2018.

Rohmaniah, Nur, "Studi Komparasi Bimbingan Perkawinan Bagi
Calon Pengantin Sebagai Upaya Mencegah Perceraian (Di KUA Kecamatan Boja dan Limbangan Kabupaten Kendal)". Skripsi. Fakultas Dakwa dan Komunikasi Universitas Islam Negeri Walisongo Semarang, 2015.

Roiatun, Siti, "Bimbingan Pra Nikah Untuk Mencegah Perceraian Bagi Calon Pengantin Di BP4 KUA Kecamatan Japah Kabupaten Blora". Skripsi. Fakultas Dakwah dan Komunikasi, Universitas Islam Negeri Walisongo, Semarang, 2017.

Saebani, Beni Ahmad, Fiqh Munakahat 1, Bandung: Pustaka Setia, 2009.

Santoso, "Hakekat Perkawinan Menurut Undang-Undang Perkawinan, Hukum Islam Dan Hukum Adat", dalam Yudisia: Jurnal Pemikiran dan Penelitian Sosial Keagamaan, Vol. 7, No. 2, Desember (2016).

Sihombing, Eka N.A.M., Kedudukan Anak Luar Nikah Pasca Putusan MK Nomor 46/PUUVIII/2010, accessed onsumut.kemenkumham.go.id (10 June 2020).

Soelaeman, Pendidikan dalam Keluarga, Bandung: Alfabeta, 1994.

Tihami, Sohari Sahrani, Fikih Munakahat (Kajian Fiqih Nikah Lengkap), Jakarta: PT RajaGrafindo Persada, 2014. 
Tutik, Titik Triwulan, Hukum

Perdata dalam Hukum

Nasional, Jakarta: Kencana

Prenada Media Group, 2008.

Yatimin, Thamrin, "Strategi Pembelajaran Akidah Akhlak Untuk Madrasah Tsanawiyah Propinsi Riau", dalam AlFikra: Jurnal Ilmiah Keislaman, Vol. 16, No. 1, Januari-Juni (2017). 